\title{
The world's tiniest land snails from Laos and Vietnam (Gastropoda, Pulmonata, Hypselostomatidae)
}

\author{
Barna Páll-Gergely | ORCID: oooo-ooo2-6167-7221 \\ Plant Protection Institute, Centre for Agricultural Research, ELKH, \\ Herman Ottó út 15, 1022 Budapest, Hungary \\ pall-gergely.barna@atk.hu,pallgergely2@gmail.com
}

Adrienne Jochum | ORCID: oooo-ooo2-6624-6412

Naturhistorisches Museum der Burgergemeinde Bern, 3005 Bern, Switzerland Institute of Ecology and Evolution, University of Bern, 3012 Bern, Switzerland Senckenberg Forschungsinstitut und Naturmuseum, 60325 Frankfurt am Main, Germany adrienne.jochum@senckenberg.de

Jaap J. Vermeulen | ORCID: Oooo-0002-8505-0319

JK Art and Science, Lauwerbes 8, 2318 AT Leiden, The Netherlands

jk.artandscience@gmail.com

Katja Anker | ORCID: 000o-0002-5350-0979

JK Art and Science, Lauwerbes 8, 2318 AT Leiden, The Netherlands jk.artandscience@gmail.com

András Hunyadi

Adria sétány $10 \mathrm{G} 2 / 5,1148$ Budapest, Hungary

hunand@freemail.hu

Aydin Örstan | ORCID: oooo-ooo2-2167-5694

Section of Mollusks, Carnegie Museum of Natural History, Pittsburgh, PA 15213, USA

anothersnail@hotmail.com

Ábel Szabó | ORCID: oooo-0oo3-0646-2639

Lithosphere Fluid Research Laboratory, Institute of Geography and Earth Sciences, Eötvös University, Pázmány p. sétány 1/C, 1117 Budapest, Hungary abel.szabo@ttk.elte.hu 


\section{László Dányi}

Institute for Soil Sciences and Agricultural Chemistry, Centre for Agricultural

Research, ELKH, Herman Ottó út 15, 1022 Budapest, Hungary

laszlodanyi@gmail.com

Menno Schilthuizen | ORCID: oooo-0oo1-6229-0347

Naturalis Biodiversity Center, Darwinweg 2, 2333 CR Leiden, The Netherlands

Institute for Biology Leiden, Leiden University, Sylviusweg 72, 2333 BE Leiden,

The Netherlands

Institute for Tropical Biology and Conservation, Universiti Malaysia Sabah,

Jalan UMS, 8840o Kota Kinabalu, Sabah, Malaysia

menno.schilthuizen@naturalis.nl

RECEIVED: 13 SEPTEMBER 2021 | REVISED AND ACCEPTED: 19 NOVEMBER 2021 |

PUBLISHED ONLINE: 5 JANUARY 2022 | PUBLISHED IN PRINT: 28 JANUARY 2022

EDITOR: T. DE WINTER

\section{Abstract}

Two new, extremely small land snail species, Angustopila coprologos Páll-Gergely, Jochum \& Hunyadi n. sp. and Angustopila psammion Páll-Gergely, Vermeulen \& Anker n. sp. are described from northern Vietnam and northern Laos, respectively. The former is characterized by a rough surface sculpture and bears tiny mud granules arranged in a pattern of radial lines on its shell surface. The latter species is the new global record-holder of the tiniest land snail title, with a shell width of $0.6-0.68 \mathrm{~mm}$ and a shell height of $0.46-0.57 \mathrm{~mm}$. These measurements surpass the former records of Angustopila pallgergelyi and Acmella nana.

\section{Keywords}

Acmella - Angustopila - Arinia - miniaturization - shell - ornamentation

"Nature is nowhere as great as in its smallest."

PLINY THE ELDER

\section{Introduction}

The evolutionary drivers of extremely small body size in invertebrate animals remain contentious in evolutionary biology because it is the point where both adaptive opportunities and physical/physiological constraints begin to clash. In many groups, body size reduction can be advantageous and may become a driving force in adaptive speciation processes by which competition for the same resource is reduced (Vergnon et al., 2013). In egg parasitoid wasps, for example, extremely small body size, down to $0.3 \mathrm{~mm}$, enables specialisation on parasitizing the small eggs of small-bodied hosts (Van der Woude \& Smid, 2017). In soil invertebrates, such as mites and 
feather-winged beetles (Ptiliidae), comparably small body sizes allow food particles to be ingested that would otherwise remain unconsumed, while tininess also enables access into crevices too small for larger-bodied individuals (Grebennikov 2008; Diakova \& Polilov, $2 \mathrm{O} 2 \mathrm{O}$ ). In land snails, small body size is probably driven mostly by the accessibility of small spaces in the subsoil. Since land snails rarely show extreme food specialization, their community structure appears to be mostly influenced by the physicochemical structure of their microhabitat (Schilthuizen, 2011). With the fractal nature of crevices-within-crevices presenting niche opportunities for tiny snails, these can forage in spaces too narrow for larger competitors to enter. Since the shell is the only rigid element of a snail's body, its size and shape will be the factor that determines the 3-dimensional spaces in which subterranean snails can feed. Another evolutionary driver of reduced body size, which may act in conjunction with ecological competition, may be the opportunity to escape from predators that preferentially target larger prey items (e.g., Suchmann \& Sullivan, 200o).

In the last few years (Páll-Gergely et al. 2015; Vermeulen et al. 2015; Marzuki et al. 2016; Dumrongrojwattana et al. 2021), tinier and tinier land snails have been described, repeatedly breaking records of previous, small-shell record-holders. Here, we describe two new land snail species of the genus Angustopila Jochum, Slapnik \& Páll-Gergely, 2014 from Laos and Vietnam, which are among the tiniest land snails ever reported. The species from Laos is also remarkable in that living individuals place mud granules (probably their own faeces), like minuscule mosaic stones, in an apparent pattern of regularly spaced radial lines on their shell surface. The other species from Vietnam, lacks external adornment and currently represents the world's tiniest known terrestrial snail.

\section{Materials and methods}

The electronic version of this article in Portable Document Format (PDF) will represent a published work according to the International Commission on Zoological Nomenclature (ICZN), and hence the new names contained in the electronic version are effectively published under that Code from the electronic edition alone. This published work and the nomenclatural acts it contains have been registered in ZooBank, the online registration system for the ICZN. The ZooBank LSID s (Life Science Identifiers) can be resolved and the associated information viewed through any standard web browser by appending the LSID to the prefix http://zoobank.org/. The LSID for this publication is: urn:lsid: zoobank.org:pub:947D88E4-53D-4631-6EE-

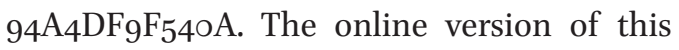
work is archived and available from the following digital repositories: PeerJ, PubMed Central SCIE and CLOCKSS.

\section{Collecting methods}

Material collection followed that of Tweedie (1961) (see also methods in Páll-Gergely et al., 2018). Soil was gathered at the base of limestone rocks and inside caves, and placed in a bucket of water, the floating scum containing plant debris and shells was removed and dried, and the shells were later sorted under a stereo microscope.

\section{Imaging, measurements}

Shells of Angustopila coprologos n. sp. were imaged via a Nikon SMZ25 digital microscope with Nikon Nis-Elements software. Scanning electron microscope images of the two new species were made using a Hitachi TM40oo Plus SEM at the Research and Instrument Core Facility of the Faculty of Science, Eötvös Loránd University, Budapest, Hungary. A Keyence VHX 5000 microscope was used to 
measure the shells of the two new species. Measurements of Acmella nana were taken using the microscale (eyepiece reticle) of a Wild M8 stereo microscope.

Only a single population of Angustopila psammion n. sp. was available, whereas for Acmella nana, 5 populations are known. To determine which species was the smallest for our measurements, we chose the Acmella nana population with the smallest shells (Kinabatangan Valley, Gomantong Hill, 30 km south of Sandakan).

To estimate volumes, the Angustopila and Acmella nana shells were assumed to be cones and the Arinia micro shells cylinders. The umbilicus volumes were subtracted from the volumes of the Angustopila shells, but no corrections were applied to the volumes of the Arinia micro and Acmella nana shells because they have very narrow umbilici. To estimate the volume of the umbilicus of an Angustopila shell, the shape of the umbilicus was assumed to be a truncated cone. The diameters of the base and the top of the truncated cone were equated to the diameters of the umbilicus and the protoconch visible through the umbilicus respectively. The height of the truncated cone (umbilicus depth) was calculated by subtracting the estimated height of the protoconch from the shell height. All dimensions were measured on photographs.

\section{Elemental composition of Angustopila coprologos shell and mud granules}

BSE SEM images, elemental composition spot measurements, and elemental maps were produced using a Hitachi TM40oo Plus SEM equipped with Quantax 75 SDD EDS system at the Research and Instrument Core Facility of the Faculty of Science, Eötvös Loránd University (Budapest, Hungary). The elemental composition was detected by using an emission current of $0.8 \mathrm{nA}$ and an electron beam acceleration voltage of $15 \mathrm{kV}$. The small granules on snail shells were measured by spot analyses (each spot for 3 o seconds).

\section{Abbreviations}

CUMZ Chulalongkorn University Museum of Zoology (Bangkok, Thailand)

HA Collection of András Hunyadi (Budapest, Hungary)

HNHM Hungarian Natural History Museum (Budapest, Hungary)

JJV Collection of Jaap J. Vermeulen (Leiden, The Netherlands)

SMF Senckenberg Forschungsinstitut und Naturmuseum (Frankfurt am Main, Germany)

VNMN Vietnam National Museum of Nature (Hanoi, Vietnam)

ZRC Zoological Reference Collection of the Lee Kong Chian Natural History Museum, National University of Singapore

\section{Results}

\section{Volume calculation}

The calculated volumes of the smallest individuals of Angustopila psammion n. sp. Angustopila coprologos n. sp., Arinia micro, and Acmella nana were $0.036,0.047,0.073$ and $0.044 \mathrm{~mm}^{3}$, respectively (see also table 1 ).

\section{Morphology of the granules}

Shells of living Angustopila coprologos n. sp. individuals and freshly dead shells possess rounded or elongated granules on the shell, arranged in radial lines starting from the umbilicus up to the dorsal shell surface. Morphologically, the granules resemble the faecal pellets of terrestrial caenogastropods rather than the elongated, rope-like excrements of pulmonates (Hirano et al., 2019). 
TABLE 1 Measurements $(\mathrm{mm})$ and calculated volumes $\left(\mathrm{mm}^{3}\right)$ of the four smallest species

\begin{tabular}{llllll}
\hline & Hs & Ds & Vtotal & Vumbilicus & Vshell \\
\hline Angustopila psammion & 0.48 & 0.6 & 0.045 & 0.00913 & 0.036 \\
Angustopila coprologos & 0.51 & 0.66 & 0.057 & 0.0104 & 0.047 \\
Arinia micro & 0.8 & 0.34 & 0.073 & negligible & 0.073 \\
Acmella nana & 0.67 & 0.5 & 0.044 & negligible & 0.044
\end{tabular}

The radial pattern is best visible on the last whorl. The majority of shells show apparent, brown-coloured granulation whereas a few shells are adorned with whitish granules. Of 300 randomly selected shells, 87 were studded with granules on their shell surfaces (all others were probably long dead and their granules worn off). Seventy-two shells had brown granules and 15 bore whitish granules (fig. 2).

\section{Elemental composition of the granules}

Twenty-one representative EDS point measurements were selected to represent the elemental composition of the snail shells with the whitish and brownish granules (seven for each). The selected measurements were averaged for comparison. The measurements were made on untreated snail shell surfaces, where the presence of elements below $5 \%$ weight can be due to an uneven and contaminated sample surface. Snail shells are composed of calcium carbonate $\left(\mathrm{CaCO}_{3}\right)$. The elemental composition of the whitish granules is very similar to that of the composition of snail shell (table 2). High carbon (C), calcium (Ca), and oxygen (O) content suggest the crystalline composite calcite and aragonite (i.e., limestone). In contrast, the composition of brownish granules can be characterised by lack of carbon (C) and high aluminium $(\mathrm{Al})$, silicon $(\mathrm{Si})$ and iron $(\mathrm{Fe})$ content (table 2), implying aluminosilicates, which are a base component of soils and rocks as well as major components of kaolin and other clay minerals.
TABLE 2 Results of EDS measurements on shells of Angustopila coprologos n. sp. and the granules on them

Shell Whitish Brownish

\begin{tabular}{lccl}
\hline \multirow{2}{*}{$\begin{array}{l}\text { Number of } \\
\text { measurements }\end{array}$} & \multicolumn{3}{c}{ average compositions } \\
\cline { 2 - 4 } & $\mathbf{n}=7$ & $\mathbf{n}=7$ & $\mathbf{n}=7$ \\
\hline Element & $\mathbf{w t} \%$ & $\mathbf{w t} \%$ & $\mathbf{w t} \%$ \\
\hline $\mathrm{C}$ & 13.8 & 17.4 & 0.0 \\
$\mathrm{O}$ & 53.2 & 58.4 & 44.2 \\
$\mathrm{Al}$ & 3.2 & 2.0 & 21.6 \\
$\mathrm{Ca}$ & 27.8 & 21.3 & 12.5 \\
$\mathrm{Si}$ & 1.3 & 0.5 & 12.1 \\
Fe & 0.7 & 0.3 & 9.6 \\
Total & 100.0 & 100.0 & 100.0
\end{tabular}

\section{Systematic descriptions}

Family Hypselostomatidae Zilch, 1959

Genus Angustopila Jochum, Slapnik \& PállGergely, 2014

Angustopila Jochum, Slapnik \& Páll-Gergely, 2014; Jochum et al., 2014: 410: 26.

Type species: Systenostoma tamlod Panha \& Burch, 1999, by original designation.

Angustopila coprologos Páll-Gergely, Jochum \& Hunyadi n.sp.

urn:lsid:zoobank.org:act:D4A1491F-EA4B4453-8FD9-73175ooCEC28 


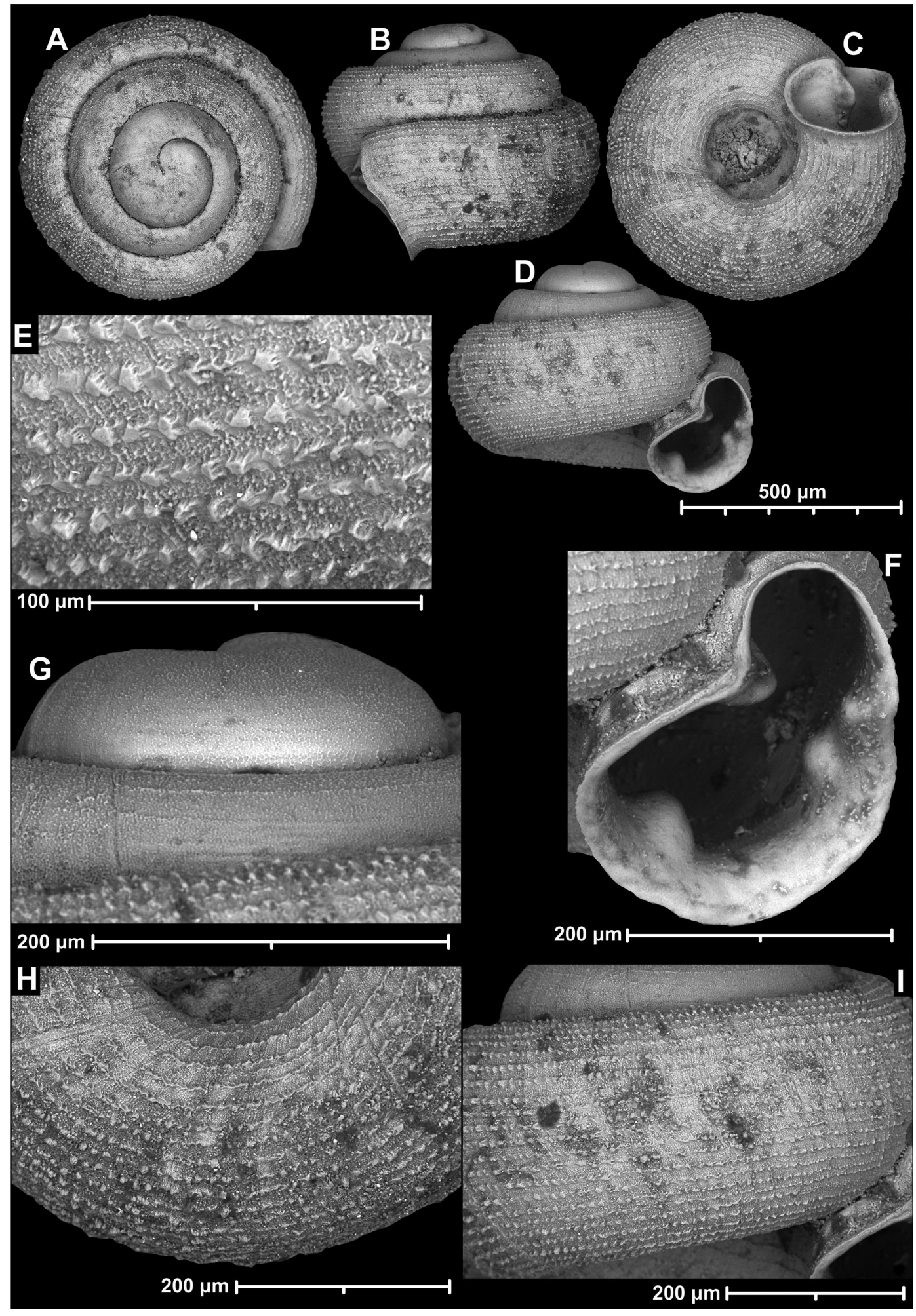

FIGURE 1 Angustopila coprologos n. sp. (holotype). 


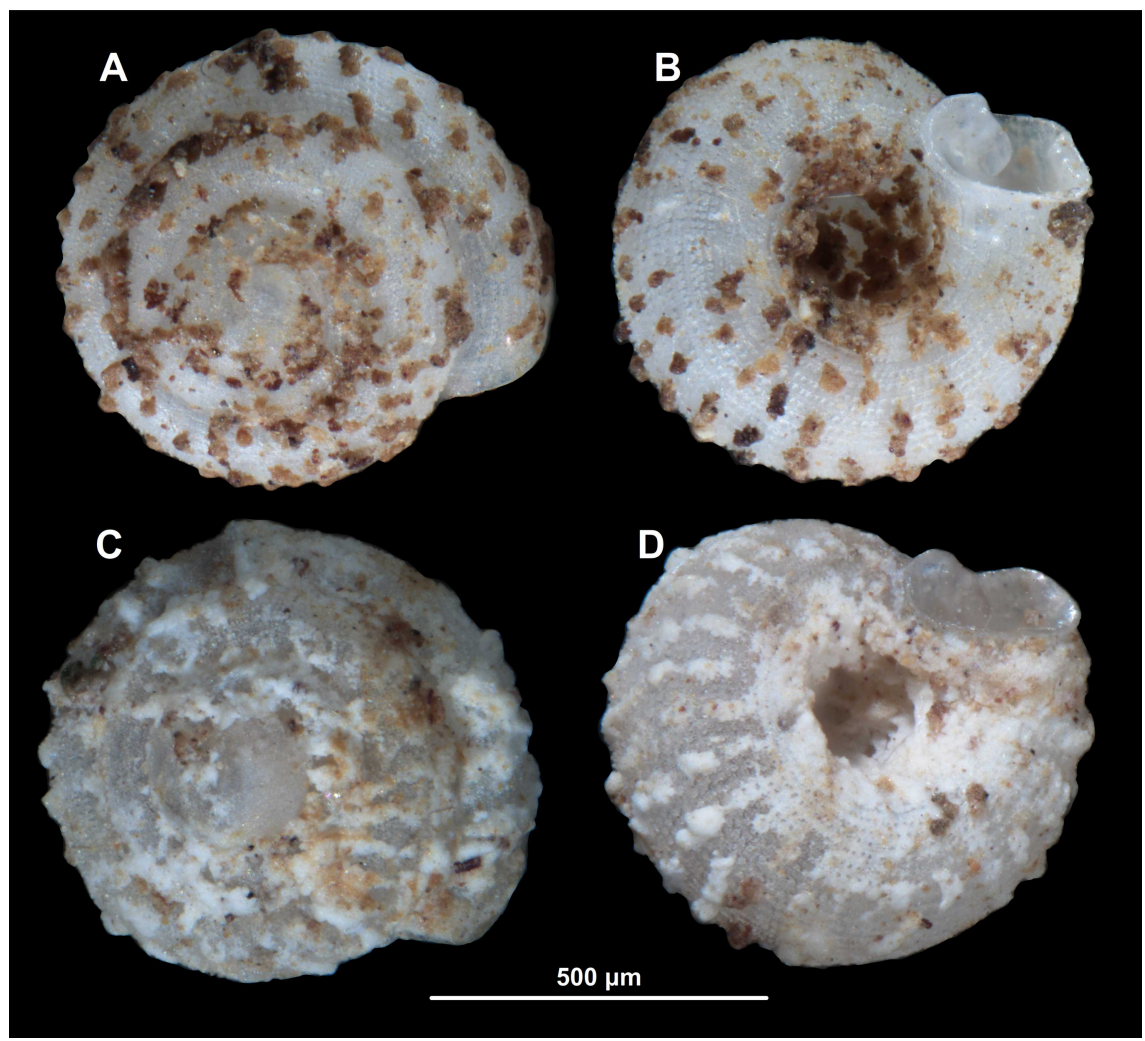

FIGURE 2 Granules on the shell surface of A. coprologos n. sp. shells. A-B shows a shell with brown 'mud', whereas $\mathrm{C}-\mathrm{D}$ shows a shell with white (calcareous) granules.

Type material: Laos, Bolikhamsai Province, 15 $\mathrm{km}$ southeast $+4.5 \mathrm{~km}$ northeast (on a side road) towards centre of Lak Sao, Phu Phako, limestone gorge, $510 \mathrm{~m}$ a.s.l., $18^{\circ} \circ 6.546^{\prime} \mathrm{N}$, $105^{\circ} \mathrm{O} 3.77^{\prime} \mathrm{E}, \quad$ (locality code: 2019/110), leg. A. Hunyadi, 2 October 2019, holotype (HNHM 104885); CUMZ 7435/2 paratypes; SMF 365053/2 paratypes; VNMN/2 paratypes; ZRC.MOL.23217/2 paratypes, HA/697 paratypes.

Diagnosis: A strongly depressed-globular Angustopila species with a wide umbilicus, strong spiral sculpture consisting of a series of coarse elevations (flat-topped beads) in a chain-like pattern and four well-developed teeth (1 parietal, 2 palatal, 1 basal).

Description: Shell tiny, whitish, strongly depressed-globular, dorsal part domeshaped, body whorl widest in standard apertural view; protoconch with slightly less than 1.5 whorls and a minute and very uneven pattern of polygonal, rather sharpcrested ridges locally forming minute, conical peaks where ridges split (the structure also reminiscent of cross-sectional trabecular bone); this surface structure forms raised spiral striae on last half of protoconch whorl, and gradually becomes stronger towards first teleoconch whorl; teleoconch bears similar basal sculpture as that of protoconch, strongly ornamented by a pattern of elevated, equidistantly-arranged rows of elegantly linked flat-topped beads; some fine, irregular radial sculpture also visible, but none especially conspicuous due to prominent bead-like striations; whorls 3.25-3.5, separated by deep suture; whorls slightly shouldered; aperture oblique to 
shell axis in lateral view; umbilicus wide, ca. one third of shell width, in living specimens containing several mud granules; aperture narrow, semilunar, sinulus relatively wide, rather strongly separated due to strong parietal tooth; peristome expanded, not reflected; parietal callus strongly protruding, remarkably visible in lateral perspective as projecting beyond peristome and nearly in line with shell periphery, detached from penultimate whorl; parietal tooth strongly developed, long, curved, pointing towards upper palatal tooth; palatal wall with an upper, smaller tooth situated at peristome edge, and a slightly larger, lower tooth situated somewhat deeper, both blunt; columellar/basal, tooth blunt with wide base, positioned on lower part of columellar area, located at similar distance from peristome edge as lower palatal tooth.

Soft anatomy unknown.

Measurements (in $\mathrm{mm}$ ): $\mathrm{sW}=0.66-0.76 ; \mathrm{sH}$ $=0.49-0.58(\mathrm{n}=19)$.

Differential diagnosis: Angustopila coprologos n. sp. can be easily distinguished from all other Angustopila species by its depressed shell, the four apertural denticles and the pronounced sculpture.

Etymology: The specific epithet coprologos (Ancient Greek for dung gatherer) refers to the mud granules (here assumed to be faeces) placed on this species' shell. Used as a noun in apposition.

Distribution: This species is known only from the type locality in Bolikhamsay Province, Laos: ca. $13 \mathrm{~km}$ southeast (in a straight line) from the town Lak Sao (see also supplementary figs $\mathrm{S}_{1}-\mathrm{S}_{2}$ ).

Habitat: Since no living individuals were found (only shells of freshly dead specimens), no observations about the specific habitat of Angustopila coprologos n. sp. could be made. The living snails presumably live deep in limestone crevices close to (or on) root systems.
The summer of 2019 was very wet and rainy with extensive flooding throughout the flood plains of the Mekong River. This might have played a role in the vast accumulation of empty shells at the base of rock formations (collection in October 2019).

\section{Angustopila psammion Páll-Gergely, Anker} \& Vermeulen, n. sp.

urn:lsid:zoobank.org:act:EAD 52AC1-985A48E7-8AF9-4C2629C416BF

Type material: Vietnam, Quang Ninh Province, Ha Long Bay, Cap La Cave, $2^{\circ} 51.793^{\prime} \mathrm{N}$, $107^{\circ} 13.541^{\prime} \mathrm{E}$, soil deposit fallen through roof in pristine cave, vegetation outside cave tall and woody, leg. J.J. Vermeulen \& K. Anker, o7 March 2018, holotype (HNHM 104886); CUMZ 7436/2 paratypes; SMF 365052/2 paratypes; VNMN/2 paratypes; ZRC.MOL.23218/2 paratypes, JJV 17633/409 paratypes.

Diagnosis: An Angustopila species with a depressed-globular shell with dome-shaped spire, thick spiral striae, kidney-shaped aperture with single parietal denticle not reaching parietal callus.

Description: Shell tiny, off-white, depressed-globular form with domed spire; body whorl widest in standard apertural view; protoconch with 1.5 whorls and a minute and very uneven pattern of polygonal, rather sharp-crested ridges locally forming minute, conical peaks where ridges split (the structure also reminiscent of cross-sectional trabecular bone), no spiral striation discernible; teleoconch ornamented by some weak radial growth lines and much stronger, ropelike, equidistantly-arranged spiral striae (ca. 14-15 on body whorl from standard apertural view); the 3.25-3.5 whorls are separated by a deep suture; whorls slightly shouldered; aperture oblique to shell axis in lateral view; umbilicus relatively wide, less than one third of shell width; aperture kidney-shaped with strongly concave parietal side; sinulus wide, 


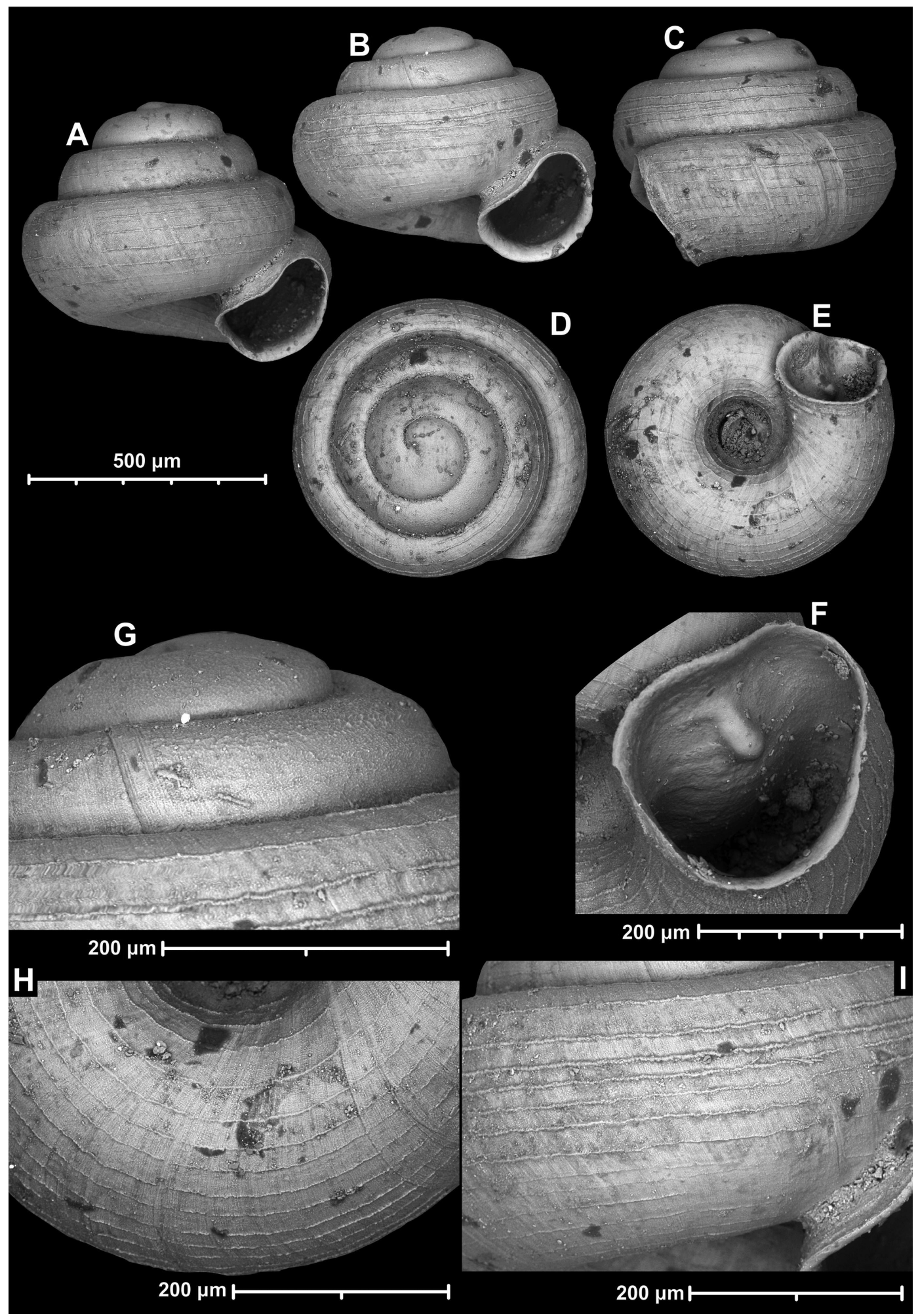

FIGURE 3 Angustopila psammion n. sp. A: paratype, B-I: holotype. 
weakly separated due to weak parietal tooth; peristome expanded, not reflected; parietal callus strongly protruding, but in line with curvature of penultimate whorl and beyond aperture edge (profile) in lateral view (fig. $3 \mathrm{C}$ ), detached from penultimate whorl; parietal tooth weak, low, short, rounded, does not reach peristome.

Soft anatomy unknown.

Measurements (in $\mathrm{mm}): \mathrm{SW}=0.6-0.68, \mathrm{~s} \mathrm{H}=$ 0.46-0.57 $(\mathrm{n}=24)$.

Differential diagnosis: Angustopila pallgergelyi Dumrongrojwattana, Chuenit \& Wongkamhaeng, 2021 is similar in shell and aperture shape, but is larger, has a prominent palatal tooth (absent in Angustopila psammion n. sp.) and a stronger parietal tooth. Angustopila coprologos n. sp. is slightly larger, has a rough shell surface, and has an additional subcolumellar tooth and two palatal teeth.

Etymology: The specific epithet ( $\psi \alpha \mu \mu$ iov) means a grain of sand in Greek and is used as a noun in apposition.

Distribution: This new species is known only from the type locality, Cap La Cave, Ha Long Bay, Quang Ninh Province, Vietnam.

Habitat: Angustopila psammion n. sp. was found in large numbers in small sediment deposits along the walls of a dry cave (Cap La Cave), in complete darkness. We assume that the sediment had fallen in through crevices in the rock, because it contains a species-rich assemblage of bleached, opaque shells of surface-dwelling terrestrial gastropods. Shells of Angustopila psammion n. sp., however, look fresh and are probably autochthonous.

\section{Discussion}

\section{Granules on the shell of Angustopila coprologos}

Terrestrial snails often place mud granules and other debris on their shells. Members of the land snail families Acavidae, Cerastidae, Chondrinidae, Enidae, Helicinidae, Hygromiidae, Orculidae, and Valloniidae are known to encrust their shells with material such as bark debris, lichens, clay and soil (Barnacle, 1962; Herbert \& Kilburn, 2004; Allgaier, 2007; Dourson et al., 2018). The most obvious explanation is camouflage, whereby the shell blends in with its surroundings to avoid the attention of visual predators. However, this species lives presumably in the limestone crevices close to root systems, where visual camouflage makes no sense. Although camouflage might be the case for Angustopila coprologos n. sp., the multiple granules inside the umbilicus cannot be easily explained, except that they might be by-products of the shell covering process. Namely, the snail places the granules as it grows, and due to the coiling of the shell, the granules accumulate in the part that has the smallest diameter (= umbilicus). If this is true, the granules are placed spirally, and the radial arrangement of them is a secondary result.

The minute granules deposited on the shell of Angustopila coprologos n. sp. are most probably mucus-packaged faeces containing the trace elements, aluminium $(\mathrm{Al})$ and Calcium (C) from mud ingestion. The elemental analysis does not allow us to determine whether sediment or clay passed through the snail's digestive system, or if the granules were placed on the shell surface without having passed through the digestive system. The former scenario is more likely because, first, the snails probably consume the clay to access the digestible organic material it contains, and therefore, the faeces would be similar in elemental composition and appearance to the mud granules. Granules, if they are really of fecal origin, contain the metabolic by-products associated with eating microorganisms and fungi contained in the mud, in conjunction with proteins and enzymes from the mucus of the snail's 
alimentary tract. Therefore, they may play a role in chemical communication by providing information to conspecific snails (Holland et al., 2018). A third possibility is that they play a role in water conservation. Snails employ strategies aimed at protecting their moist surfaces from dryness, avoidance of temperature extremes, the establishment of favoured microclimates, and decreases in gas exchange (Cook, 2001; Schweizer et al., 2019). Similar to the function ascribed to ribbing (radial sculptural elements) on shell surfaces of other land snails (Giokas et al., 2014), mud granules may help in retaining more water on their shells.

\section{The smallest terrestrial snails}

In 2015, Angustopila dominikae Páll-Gergely \& Hunyadi, 2015 was reported to be the world's smallest terrestrial snail with a maximum shell height of $0.86 \mathrm{~mm}$ (Páll-Gergely et al., 2015). Only two months later, an even smaller land snail, Acmella nana Vermeulen, Liew \& Schilthuizen, 2015, was described (shell height o.6o-0.79 mm, shell width $0.5^{0}-0.60 \mathrm{~mm}$; Vermeulen et al., 2015). Soon thereafter, yet another tiny Southeast Asian species, Arinia micro Marzuki \& Foon, 2016 (shell height: o.80-0.90 mm, shell width $0.34-0.35 \mathrm{~mm}$ ) was reported. More recently, an Angustopila species smaller than Angustopila dominikae was published as Angustopila pallgergelyi, with a shell width of $0.76-0.85 \mathrm{~mm}$ and a shell height of $0.59^{-0.71} \mathrm{~mm}$ (Dumrongrojwattana et al., 2021). In this paper, we describe two even smaller members of this genus: Angustopila coprologos n. sp. with a shell width of o.66$0.76 \mathrm{~mm}$ and a shell height of $0.49^{-0.58 \mathrm{~mm}}$ and a second new species, Angustopila psammion n. sp. (shell width: o.6-o.68, shell height: 0.46-0.57 mm) (figs 4-5). Rivalling both Acmella nana and Arinia micro, Angustopila psammion n. sp. now appears to set the newest record for the world's tiniest terrestrial snail. Although the shell height of Arinia micro is greater than the greatest height measurements of the other two species, its shell shape is much more slender (i.e., the shorter shell measurement is comparatively smaller than in Acmella nana and Angustopila psammion $\mathrm{n}$. sp., so among of all these species, Arinia micro could pass through the smallest hole).

These considerations underscore that it is important to investigate more metrics than just height and width dimensions to determine shell size. Various methods can be used to determine which among the mentioned three candidate species (i.e. Acmella nana, Angustopila psammion n. sp., and Arinia micro) truly is the smallest.

One method is to compare the longest and shortest dimensions of the smallest known fully grown adult shell and the mean values of the smaller and longer measurements of each of the three species (Páll-Gergely et al., 2015). This is particularly difficult for Acmella nana vs Angustopila psammion n. sp. The largest measurement (shell height in the former and shell width in the latter) of the smallest specimens of the two species is identical (namely, o.6o mm). The corresponding shortest measurement for the smallest available Acmella nana shell is $0.59 \mathrm{~mm}$, whereas it is $0.48 \mathrm{~mm}$ in Angustopila psammion n. sp., suggesting that the new species is smaller. The mean values of the smallest and largest measurements of Acmella nana are $0.56 \mathrm{~mm}$ and $0.63 \mathrm{~mm}$, and $0.5^{2} \mathrm{~mm}$ and $0.64 \mathrm{~mm}$ for Angustopila psammion n. sp. This indicates that the mean of the largest measurements of the spectrum for Acmella nana is slightly smaller than for Angustopila psammion n. sp., but the smallest measurement of Angustopila psammion n. sp. is considerably smaller. Thus, when considering the mean of the largest measurements, Acmella nana is the smallest, but when considering the smallest and largest measurements together, Angustopila psammion n. sp. can claim the tiniest terrestrial snail title. A 


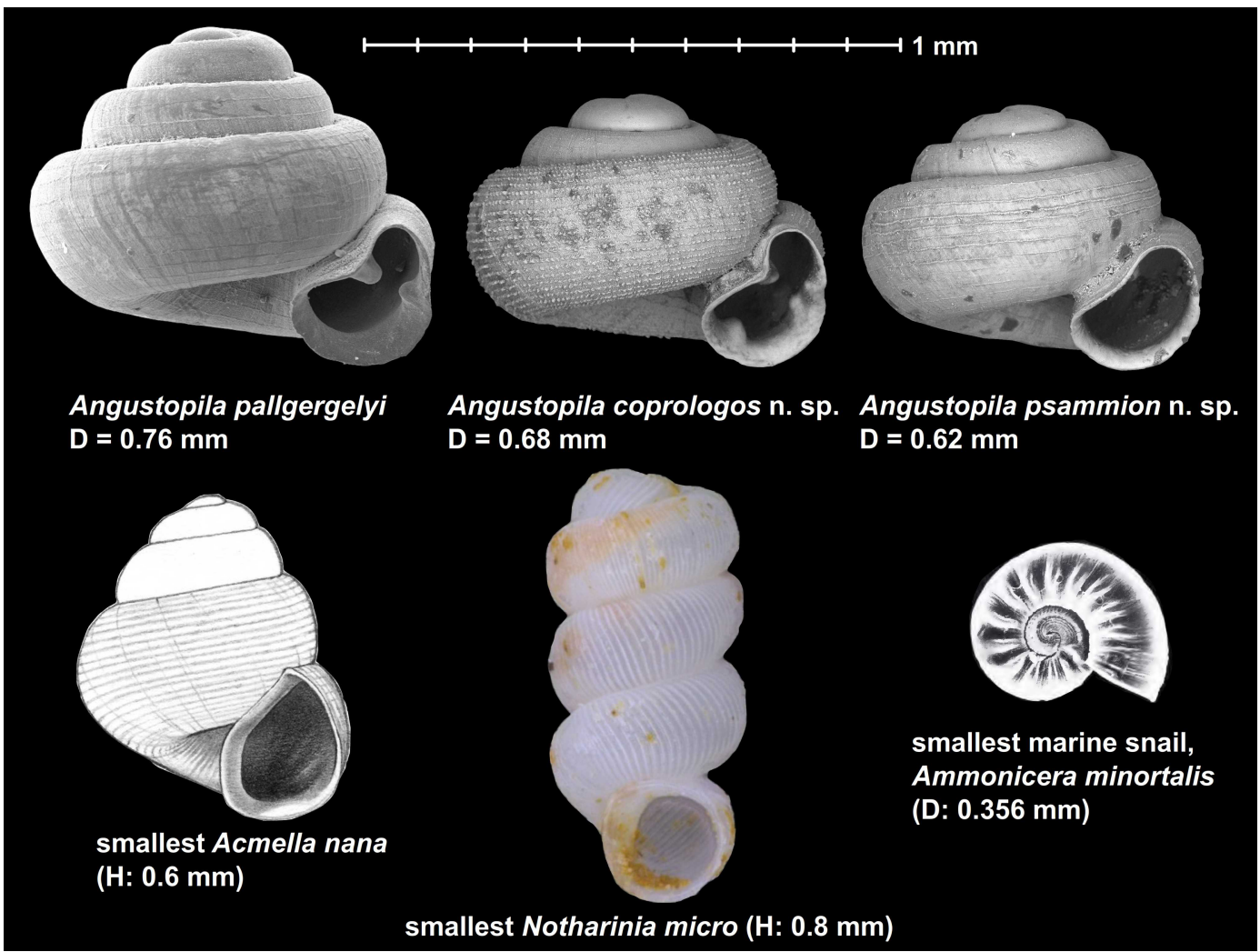

FIGURE 4 Size comparisons of the former record holders, A. pallgergelyi, Acmella nana, Notharinia micro, the smallest marine snail, Ammonicera minortalis, and the two new species described herein. The image of Ammonicera minortalis Rolán, 1992 is from Oliver et al. (2012), whereas the other images (Acmella nana and Arinia micro) are from their respective original descriptions. The figure of Acmella nana is adjusted to scale with the measurement of the smallest specimen, whereas for Angustopila coprologos n. sp. and Angustopila psammion n. sp., the holotypes (not the tiniest shells) are shown.

more relevant method for determining which is the smallest species, therefore, is to estimate volume, rather than height and width dimensions. Our calculations show that Angustopila psammion has the smallest volume among all three species, which also makes it the smallest land snail ever found (see table 3 and figs 4-5).

\section{Evolution of snail miniaturization}

There are several proposed evolutionary mechanisms that favour smaller individuals of a species and select against larger ones (Blanckenhorn, 200o; Grebennikov, 2008). For snails, the most obvious consideration is that smallness enables snails to enter a previously unoccupied niche, either by being able to forage in narrow spaces, and/or by utilizing food particles that would otherwise remain unconsumed by larger animals (Grebennikov, 2008; Diakova \& Polilov, 2020). Moreover, by being small, a snail may avoid predation either because it falls below the minimum food item size of predators or by being able to enter spaces devoid of predators.

Despite these advantages, miniaturization also subjects an organism to harsh physical and physiological limitations that probably function as evolutionary constraints. In ptiliid beetles and egg parasitoids, it is suggested that sensory receptors and the processing of stimuli 


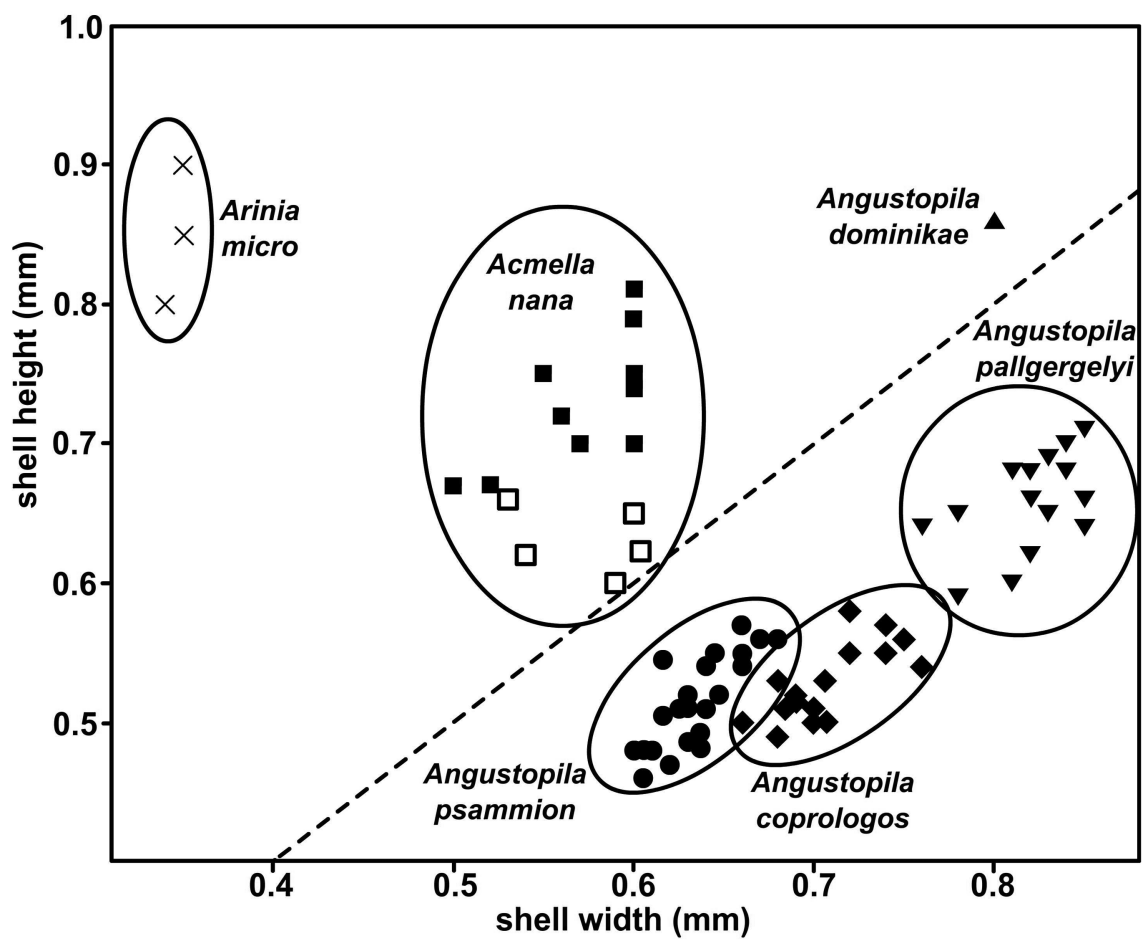

FIGURE 5 Plot of shell height against shell width (diameter) for Acmella nana, Angustopila coprologos n. sp., Angustopila dominikae, Angustopila pallgergelyi, Angustopila psammion n. sp., Arinia micro. Empty squares of Acmella nana represent shells of the population with smallest shells. The dashed line represents equal shell height and width. Ellipses drawn manually.

in the brain cease to function below a certain size, simply because the number of available cells drops below a viable threshold (Van der Woude \& Smid, 2017; Diakova \& Polilov, 202O). However, all these animals have juvenile stages that are much smaller than the adults, so it is not clear why brains and sensory organs would be too small to function in the adult, while they clearly function in much smaller larvae.

Another limiting factor may be an increased risk of desiccation given the extremely high surface-to-volume ratio in the smallest land snails. This risk may limit the evolution of the smallest snails to regions with stable climate, or specific habitats, such as caves, where humidity remains high all year round. Since this limitation is absent under aquatic conditions, this may be why a few marine snails are smaller than the smallest land snails (Rolán, 1992). For example, the shells of Ammonicera minortalis Rolán, 1992, which may, in fact, be the smallest snail overall, are $0.34-0.46 \mathrm{~mm}$ in diameter (Bieler \& Mikkelsen, 1998). These considerations suggest that the currently known tiniest marine and terrestrial snail species may be close to the organismal limits of how small adult snails can be. The smallest land snails are slightly larger than the smallest marine snails. This indicates that there may be additional limitations on miniaturization besides neuron number and desiccation (Örstan, 2018).

One of these limitations may lie in reproduction. The previously proposed minimum egg diameter of about $0.4 \mathrm{~mm}$ for land snails was based on the data available for snails 
TABLE 3 Comparison of shell measurements (in $\mathrm{mm}$ ) of the three tiniest land snails

\section{Acmella nana Angustopila Ariniamicro psammion}

Longest measurement of the smallest

0.6

0.6

0.8

shell (shell having the smallest longest

measurement) (in $\mathrm{mm}$ )

Corresponding shortest measurement of

0.59

0.48

0.34

the smallest shell (shell having the smallest

longest measurement) (in $\mathrm{mm}$ )

Longest measurement of the largest

0.66

0.68

shell (shell having the largest longest

measurement) (in mm)

Shortest measurement of the largest

shell (shell having the largest longest

0.56

0.35

measurement) (in mm)

Mean longest measurement (in $\mathrm{mm}$ )

$0.63(\mathrm{n}=4)$

$0.64(\mathrm{n}=23)$

$0.85(\mathrm{n}=3)$

Mean shortest measurement (in $\mathrm{mm}$ )

$0.56(n=4)$

$0.52(\mathrm{n}=23)$

$0.35(n=3)$

Calculated volume of the tiniest shell

0.044

0.036

0.073

(in $\mathrm{mm}^{3}$ )

( $0.67 \mathrm{~mm} \times$

(0.48 mm $\times$

(o.8 $\mathrm{mm} \times$

$0.5 \mathrm{~mm}$ )

$0.6 \mathrm{~mm})$

$0.34 \mathrm{~mm})$

In case of Acmella nana the lot containing the tiniest shells was only taken into account. Smallest volume of each comparison is in bold.

larger than the smallest Angustopila species (Baur, 1989; Örstan, 2018). The current information requires the lowering of that limit. The diameters of the protoconchs of Ammonicera minortalis shells, about $0.13 \mathrm{~mm}$ (Bieler \& Mikkelsen, 1998), and those of Angustopila coprologos and Angustopila psammion, about $0.22 \mathrm{~mm}$ (figs $1 \mathrm{~A}, 3_{3} \mathrm{D}$ ), give an indication of the minimum viable sizes of neonate snails. The dimensions of the eggs of the smallest snails would be slightly larger than the smallest viable hatchlings. Egg size then might become the principal determinant of the minimum possible volume of an adult snail that is going to accommodate at least one egg (Rensch, 1959; Örstan, 2018). Since the egg must fit within the body whorl of the shell as well as pass through the aperture, additional constraints are equally imposed on the shape of the shell and both the shape and the dimensions of the aperture. We note that we can rule out the possibility that these snails are viviparous, because the clear protoconch-teleoconch boundary suggests reproduction by eggs. Interestingly, two of the constraints (minimum egg size and desiccation risk) imply that the smallest stylommatophoran snails should also be the most globular, which is indeed what Örstan (2018) found in his morphometric analysis. Angustopila coprologos n. sp. and Angustopila psammion fall well within this trend, as their shell heights are $\sim 75 \%$ of their shell widths.

Finding tiny land snail shells is challenging and requires special techniques (see materials and methods). It is possible that even smaller snail species exist but have remained undetected due to lack of attention 
or inadequate collecting methods. For example, too large a mesh width of sieves used to process the collected soil samples may result in losing the smallest shells. For the majority of cases however, the plant material of the soil samples floats together with the shells, entrapping the smallest shells in its often large mass of flotsam material. These minuscule shells subsequently get revealed under the microscope after being dried. Soil samples without much plant material (mostly from caves) usually consist of a rather grainy, inorganic calcareous material that when dumped in a bucketful of water, immediately releases its shells, which float in the thin foam on the surface. For Angustopila psammion n. sp., this was skimmed off with a $0.2 \mathrm{~mm}$ mesh wire sieve without further rinsing. Even particles smaller than $0.2 \mathrm{~mm}$ are trapped with this method. Thus, at least for the collectors of the present paper, we feel that we can rule out the possibility that species smaller than Angustopila psammion n. sp. are left unnoticed due to any of the above reasons, at least in this area.

\section{Conclusions}

Two species, Angustopila psammion PállGergely, Vermeulen \& Anker n. sp. and Angustopila coprologos Páll-Gergely, Jochum \& Hunyadi n. sp. are described from northern Laos and northern Vietnam, respectively. With its shell width of $0.60-0.68 \mathrm{~mm}$ and shell height of $0.46-0.57 \mathrm{~mm}$, Angustopila psammion $\mathrm{n}$. sp. is the new global recordholder of the title of the tiniest land snail, surpassing the former two record-holders, Angustopila pallgergelyi and Acmella nana. The calculated volume for the smallest adult snail (including the shell) is $0.036 \mathrm{~mm}^{3}$. In the absence of extreme food specialization, miniaturization of land snails is probably driven by the accessibility of small spaces in the subsoil, although other scenarios, such as avoidance of larger predators, cannot be ruled out. The lower limit of adult shell size may be determined by the fact that it must accommodate at least one viable egg, the size of which in turn, may be limited by the minimum number of neurons to be functional in the hatchling. On the other hand, Angustopila coprologos n. sp. is characterized by a rough surface sculpture (most complex among all known and undescribed species of its genus), and minuscule mud granules arranged in radial lines on its shell surface. These granules may play a role in camouflage and mate recognition or function like mini sponges for water retention.

\section{Acknowledgements}

We are grateful to Tim Pearce for his comments on the manuscript, and to three anonymous reviewers who provided very helpful comments. This study was supported by funding from a Bolyai Research Scholarship of the Hungarian Academy of Sciences and the Hungarian Research Fund (OTKA FK 135262) to B.P-G.

\section{Supplementary material}

Supplementary material is available online at: https://doi.org/10.6o84/mg.figshare.17143946

\section{References}

Allgaier, C. (2007) Active camouflage with lichens in a terrestrial snail, Napaeus (N.) barquini (Gastropoda, Pulmonata, Enidae). Zoological 
Science, 24(9), 869-876. https://doi.org/10.2108/ zsj.24.869.

Barnacle, G.A.S. (1962) Notes on the genus Acavus Montfort. Journal of Conchology, 25, 128-131.

Baur, B. (1989) Growth and reproduction of the minute land snail Punctum pygmaeum (Draparnaud). Journal of Molluscan Studies, 55, $383-387$.

Bieler, R. \& Mikkelsen, P.M. (1998) Ammonicera in Florida: Notes on the smallest living gastropod in the United States and comments on other species of Omalogyridae (Heterobranchia). Nautilus, 111, 1-12.

Blanckenhorn, W.U. (2000) The evolution of body size: What keeps organisms small? Quarterly Review of Biology, 75, 385-407.

Cook. L. (2001) Behavioural Ecology: On doing the right thing, in the right place at the right time. In: G.M. Barker (Ed.), The Biology of Terrestrial Molluscs. pp. 447-487. CABI Publishing, Wallingford, UK.

Diakova, A.V. \& Polilov, A.A. (2020) Sensation of the tiniest kind: the antennal sensilla of the smallest free-living insect Scydosella musawasensis (Coleoptera: Ptiliidae). PeerJ, 8, e1o4o1.

Dourson, D.C., Caldwell, R.S., \& Dourson, J.A. (2018) Land snails of Belize, Central America: A remarkable Chronicle of Diversity and Function. Goatslug Publications, USA.

Dumrongrojwattana, P., Chuenit, S. \& Wongkamhaeng, K. (2021) A new species of the world's smallest cave snail of the genus Angustopila Jochum, Slapnik \& PállGergely in Jochum, et al., 2014 (Gastropoda: Hypselostomatidae) from eastern Thailand. Raffles Bulletin of Zoology, 69, 102-108.

Giokas, S., Páll-Gergely, B. \& Mettouris, O. (2014) Nonrandom variation of morphological traits across environmental gradients in a land snail. Evolutionary Ecology, 28(2), 323-340.

Grebennikov, V.V. (2008) How small you can go: Factors limiting body miniaturization in winged insects with a review of the pantropical genus Discheramocephalus and description of six new species of the smallest beetles (Pterygota: Coleoptera: Ptiliidae). European Journal of Entomology, 105, 313-328. doi: 10.14411/eje.2008.o39.

Herbert, D.G. \& Kilburn, R.N. (2004) Field Guide to the land snails and slugs of eastern South Africa. Natal Museum, Pietermaritzburg.

Hirano, T., Asato, K., Yamamoto, S., Takahashi, Y. \& Chiba, S. (2019) Cretaceous amber fossils highlight the evolutionary history and morphological conservatism of land snails. Scientific Reports, 9, 15886, https://doi. org/10.1038/s41598-019-51840-3.

Holland, B.S., Gousy-Leblanc, M. \& Yew, J.Y. (2018) Strangers in the dark: behavioral and biochemical evidence for trail pheromones in Hawaiian tree snails. Invertebrate Biology, 137(2), 124-132.

Jochum, A., Slapnik, R., Kampschulte, M., Martels, G., Heneka, M. \& Páll-Gergely, B. (2014) A review of the microgastropod genus Systenostoma Bavay \& Dautzenberg, 1908 and a new subterranean species from China (Gastropoda, Pulmonata, Hypselostomatidae). ZooKeys, 410, 23-40.

Marzuki, M.E., bin \& Foon, J.K. (2016) A new land snail, Arinia (Notharinia) micro (Caenogastropoda: Cyclophoroidea: Diplommatinidae), from a limestone karst in Perak, Peninsular Malaysia. Raffles Bulletin of Zoology, $64,313-318$.

Örstan, A. (2018) Interplay of size and shape in miniaturized land snails. bioRxiv, 275636; doi: https://doi.org/10.1101/275636.

Páll-Gergely, B., Hunyadi, A., Jochum, A. \& Asami, T. (2015) Seven new hypselostomatid species from China, including some of the world's smallest land snails (Gastropoda, Pulmonata, Orthurethra). ZooKeys, 523, 31-64.

Páll-Gergely, B., Deli, T., Erőss, Z.P., Reischütz, P.L., Reischütz, A. \& Fehér, Z. (2018) Revision of the subterranean genus Spelaeodiscus Brusina, 1886 (Gastropoda, Pulmonata, Spelaeodiscidae). ZooKeys, 769, 13-48. 
Rensch, B. (1959) Evolution above the species level. Columbia University Press, New York.

Rolán, E. (1992) The family Omalogyridae G. O. Sars, 1878 (Mollusca, Gastropoda) in Cuba with description of eight new species. Apex, 7 , $35-46$.

Schilthuizen, M. (2011) Community ecology of tropical forest snails: 30 years after Solem. Contributions to Zoology, 8o(1), 1-15.

Schweizer, M., Triebskorn, R. \& Köhler, H.-R. (2019) Snails in the sun: Strategies of terrestrial gastropods to cope with hot and dry conditions. Ecology and Evolution, 9 (22): 12940-12960. https://doi.org/10.1002/ece3.5607.

Suchman, C.L. \& Sullivan, B.K. (200o) Effect of prey size on vulnerability of copepods to predation by the scyphomedusae Aurelia aurita and Cyanea sp., Journal of Plankton Research, 22 (12), 2289-2306. https://doi. org/10.1093/plankt/22.12.2289.
Tweedie, M.W.F. (1961) On certain Mollusca of the Malayan limestone hills. Bulletin of the Raffles Museum, 26: 49-65.

van der Woude, E. \& Smid, H.M. (2017) Effects of isometric brain-body size scaling on the complexity of monoaminergic neurons in a minute parasitic wasp. Brain, Behavior and Evolution, 89: 185-194.

Vergnon, R., Leijs, R., van Nes, E.H. \& Scheffer, M. (2013) Repeated parallel evolution reveals limiting similarity in subterranean diving beetles. The American Naturalist, 182(1), $67-75$.

Vermeulen, J.J., Liew, T.S. \& Schilthuizen, M. (2015) Additions to the knowledge of the land snails of Sabah (Malaysia, Borneo), including 48 new species. ZooKeys, 531: 1-139. doi: 10.3897/ zookeys.531.6og7. 